\title{
The Impact of the Covid-19 Pandemic along with the Development of Sustainable Tourism and Tourism 4.0 in New Normal Covid-19 Pandemic in Karimunjawa
}

\author{
Robetmi Jumpakita Pinem ${ }^{1}$, Sari Listyorini ${ }^{2}$, Dinalestari Purbawati ${ }^{3}$, Ilham Ainuddin ${ }^{4}$ \\ \{robetmi@lecturer.undip.ac.id ${ }^{1}$ \} \\ Universitas Diponegoro, Indonesia ${ }^{1,2,3,4}$
}

\begin{abstract}
The tourism sector is one of the potentials in national development, its contribution is quite high for state revenue. The purpose of this study is to determine the impact of the Covid-19 pandemic on tourism in Karimunjawa and how tourism sustainability is supported by Tourism 4.0. The Covid-19 pandemic has caused the tourism sector to experience a downturn, one of which is in Karimunjawa. The sustainability of tourism which includes 3 pillars, namely economic, social and environmental needs to be considered in the development of tourism after the COVID-19 pandemic. The realization of this sustainable tourism development needs to be supported by technology that synergizes in presenting information related to tourism destinations by prioritizing cleanliness, safety and health. This support is a strategy for tourism 4.0 that tourism service managers need to tackle in facing the downturn due to Covid-19. The economic, social and environmental impacts are quite large in influencing changes in the lives of the Karimunjawa people. Government support to overcome this problem has not had a positive impact. Tourism 4.0 support has not been fully implemented in order to develop sustainable tourism in the New Normal era in Karimunjawa.
\end{abstract}

Keywords: Pandemic Covid-19, Sustainable Tourism, Tourism 4.0

\section{Introduction}

The Travel and Tourism Competitiveness Index 2019 released by the World Economic Forum (WEF) is used as a benchmark for tourism competitiveness between countries using 4 main pillars, namely enabling environment, policy and enabling conditions, infrastructure, cultural and natural resources. The Travel \& Tourism Competitiveness Index (TTCI) 2019 shows that Indonesia is still ranked 40th below Singapore (17), Malaysia (29) and Thailand (31). Thus, special handling is still needed related to the 4 pillars of TTCI, namely enabling environment, policy and enabling conditions, infrastructure, cultural and natural resources. In the context of this increase, in the 2020-2024 national development plans, one of which is to increase the competitiveness of tourism destinations and industries which are supported by strengthening the supply chain and tourism ecosystem, including natural tourism.

Interesting tourism destinations visited by tourists are destinations that match the motives of these tourists. There are several types of tourism according to Pendit [1], namely cultural tourism, maritime tourism, marine tourism, nature reserve tourism (conservation), convention tourism, agricultural tourism, hunting tourism, and pilgrimage tourism. Marine ecotourism is defined as: marine tourism includes those recreational activities that involve travel away from 
one's place of residence and which have their host or focus on the marine environment (where the marine environment is defined as those waters which are saline and tide-affected) [2].

The Covid-19 outbreak has hit the world, one of the sectors that has had a big impact is the tourism sector. The dependence of tourism actors is very large on this sector because it is their only source of income. When tourism objects are closed, their work practically stops. The government's efforts to minimize this impact by providing incentives have not yet provided positive benefits. On the other hand, in the short term, the government needs to protect public health and the tourism industry by preventing some of the worst effects of Covid-19. Incoming tourists need to first quarantine for 2 weeks, this is a separate obstacle for tourists, so they need a careful and careful approach. This condition is prepared with a set of general rules regarding departure and arrival procedures as well as sanitary requirements on the way. In the medium and long term, the government must support economic diversification so that it does not depend on one sector as the foundation of the economy (United Nations Conference on Trade and Development, 2020).

Sustainable tourism is an important aspect for the development of tourism affected by Covid-19. The concept of sustainability is related to how the tourism sector can maintain, care for and manage with the support of quality human resources. This was reinforced by the UN World Tourism Organization (UNWTO) which issued 'One Planet Vision for the Responsible Recovery of the Tourism Sector' as a reinforcement of UNWTO guidelines for restarting tourism after the Covid-19 pandemic. The Ministry of Tourism and Creative Economy issued a CHS (Clean, Healthy, Safety) program. This program has actually been stated in sustainability tourism. Hygiene, health and safety indicators are found in the governance pillar in Permenpar No.14/2016. So that if the destination has implemented sustainable tourism, it will be easy to adopt the CHS in the new normality [3].

Tourists will have a tendency to support sustainable tourism after the Covid-19 pandemic, such as avoiding destinations that are too crowded, bringing their own food and drinking supplies so that the impact is to reduce waste or plastic waste that disturbs natural sustainability. This trend will be carried out by tourists using digital devices such as smartphones, tablets, or laptops. Tourists are now more concerned with health and safety by adjusting the sanitation needs, distance and food restrictions from accommodation service providers and tourism destinations. The use of digital as information support for this tourism destination is known as Tourism 4.0. If Industry 4.0 aims to achieve higher value-added products and services through operational efficiency and automation of the production process by utilizing modern technology, Tourism 4.0 is aimed at doing the same for the tourism sector [4].

Karimunjawa is a potential tourist who likes the beauty and preservation of nature. The sustainability of tourism related to the economy, social and environment is a requirement for tourism development after experiencing the impact of Covid-19. With the support of the tourism 4.0 strategies, the realization of tourism sustainability will be realized.

\section{Literature Review}

\subsection{Tourism 4.0}

According to the WTO (World Trade Organization) in Richardson \& Flucker [5], tourism is a human activity that travels and lives in a destination outside of their daily environment. Meanwhile, according to Matheison \& Wall (1982) quoted by Cooper [6], tourism is a 
temporary journey to a destination outside the home and workplace, activities carried out while in place using facilities designed to serve tourists. According to Peceny et al. [7], said that tourism 4.0 is a collaboration to form a collaborative ecosystem that involves local communities, local governments, tourism, service providers and government together to create enriched tourism experiences both physically and non-physically. The essence of tourism 4.0 is using technology to promote positive environmental, social and economic conditions and collaboration among all stakeholders in the ecosystem. According to Manjari [8] considers Tourism 4.0 as a new stage of tourism development Compared to E-tourism and M-tourism, it is: 1.E-tourism refers to the digitization of tourism companies and includes establishing commercial relationships using the Internet to offer tourism services, for example ordering hotel, flight ticket or car service; 2. M-tourism is understood to represent the accumulation of tourism-related interactions obtained through mobile devices (for example, GPS, electronic maps, information about attractions, shops, restaurants, etc.).

\subsection{Sustainable Tourism for Development (Stdev)}

The basic requirements of the tourism sector are to have the principles of sustainable tourism and focus on achieving the goals of sustainable development. Sustainable tourism must not be a separate component from tourism as a unit but as a whole tourism that must achieve sustainability. UNWTO defines sustainable tourism as tourism that focuses fully on current and future economic, social and environmental impacts, addressing the needs of visitors, industry and the environment and host communities.

Sustainable tourism development requires informed participation of all relevant stakeholders and strong leadership politics to achieve participation and development consensus. This development requires constant impact monitoring, preventive/corrective action required at any time. Sustainable tourism must also maintain a level of tourist satisfaction and a meaningful experience for tourists, raise their awareness of sustainability issues and promote sustainable tourism practices among them.

\subsection{Sustain and Tourism 4.0}

Tourism 4.0 technology needs to be directed at improving the quality of tourism with the assumption of intelligence and sustainability as a paradigm to improve the quality of life and social value of visitors and local residents [9]. Sustainable tourism is at the core of Tourism 4.0 which aspires to use technology to drive positive environmental, social and economic impacts and collaboration between all stakeholders in the ecosystem. This will be achieved by synergizing motivation and rewards to produce positive behavior, namely positive behavior towards the impact of the social and economic economy on a destination, both tourists and other stakeholders. In this way it is a driving force for the sustainable development of the whole society. This will be achieved if there is intensity and quality of communication between them.

\section{Research Methods}

The research used is qualitative research using descriptive methods, because in this research the researcher tries to describe the actual processes and events. Based on the theory of qualitative research, the researcher believes in using descriptive research methods, because 
this research method is centered on descriptions in the form of sentences that have deep meanings that come from informants with various relevance. This research focuses on: (1) the economic, social and environmental conditions of Karimunjawa during the Covid-19 pandemic, (2) sustainable tourism as tourism development after the Covid-19 pandemic, (3) tourism 4.0 as a technology that supports the sustainability of post-pandemic tourism 19 .

The research location is in Karimunjawa. Sources of data obtained by researchers are primary data and secondary data. There are 3 data collection conducted by researchers, namely interviews, observation and documentation. The criteria for key informants are those who know and manage Karimunjawa tourism. Interviews were conducted to tourism managers, Balai Taman Nasional and local communities. The research was conducted during JuneAugust 2020. Meanwhile, the research instrument was the researcher himself, the interview guide. Researchers used the Interactive Model Data Analysis according to Miles and Huberman [10].

\section{Results and Discussion}

\subsection{Karimunjawa's Economic, Social and Environmental Conditions during the Pandemic}

Since March 17, 2020 Karimunjawa National Park is closed for visitors or tourists. This closure also applies to ship passengers from outside the Karimunjawa area, including even from other sub-districts in Jepara, except for official matters and logistics delivery. Currently, tourism managers in Karimunjawa are waiting for the reopening of this National Park by preparing tour packages for individual travelers, groups or families. According to the Jepara Regency Tourism and Culture Office, the opening of this destination is waiting for the development of the pandemic to decline.

In a few months of the Covid-19 pandemic, the islands of Karimunjawa District, Jepara Regency were the only areas where there were zero cases of Covid-19 in Central Java. Although it is safe, the fact is that currently in August 2020 it has not been opened at all for visitors carrying out tourism activities. This depends on the preparation of Karimunjawa residents for the implementation of the New Normal. The closure of the Karimunjawa object resulted in a decrease in the number of visitors or tourists so that this condition affects several aspects of sustainable tourism in Karimunjawa. Aspects that affect environmental, social and economic aspects:

\subsubsection{Environmental Conditions}

This environmental condition highlights the risk of a pandemic to the Karimunjawa marine environment, the attention and protection of local communities and tourism actors to the tourism environment during the pandemic, water quality and maintenance of marine ecosystems during the pandemic. The decrease in the number of tourist visits has an impact on the cleanliness of the Karimunjawa National Park. The lack of tourism objects does not discourage officers from always cleaning the environment from debris that damages the marine ecosystem. Before the pandemic, the tourists had a very high environmental awareness because they were willing to keep the environment clean there. At the time of this pandemic, the condition of Bobi beach which is usually rarely visited by tourists is still in clean condition because the officers are responsible for cleaning it. Unlike the condition of Tanjung Gelam 
beach which was crowded with visitors before the pandemic, during the pandemic, this beach was neglected because it was empty of visitors.

The marine ecosystem that was in the sea or its surroundings during this pandemic was maintained due to the commitment of tourism actors to protect the existing ecosystem. The environment in the sea is protected from plastic debris that is washed away in the Karimunjawa waters because it is immediately cleaned and dumped on land. This is usually done by guides for water tourism activities at local locations on a regular basis every few months. The ability to clean this garbage is usually done by guides both before and during a pandemic so that there is no change in habits in protecting marine ecosystems. During the pandemic, the garbage does not come from tourists but from other marine areas.

The quality of seawater before and during the pandemic has not changed, whether there are tourists who dive or not. Before the pandemic, most of the tourists who came were beginners who were not good at doing water activities, so that when they were underwater, they bumped into many coral reefs. This condition makes coral reefs damaged and not maintained. At the time of the pandemic which has been running for about 5 months, the coral reefs are still well maintained and even develop.

\subsubsection{Social Condition}

Before the pandemic, the social conditions in the Karimunjawa community were very good, both between the internal social relations of the community itself or the relationship with tourists who visited there. The culture that is rooted in the Karimunjawa society is well appreciated by visitors so that local cultural values are still respected and tolerant of these values. Since access was closed from outside Karimunjawa during the pandemic, the community did not interact with outside parties. It has a very significant impact on local community income generation, thereby changing existing social values. The Jepara Regency Government still allows the implementation of cultural traditions that are usually carried out by the Karimunjawa people but with the covid-19 health security guarantees that the local village government can strive for. Logistic assistance from outside parties to the community is sufficient to help meet basic needs. Kapolda Jawa Tengah handed over 200 basic food packages, 2,000 masks and 50 liters of hand sanitizer to Karimunjawa residents (August, 2020). However, the aid is not continuous so that people continue to rely on income from this livelihood.

The interactions that occur between communities have also changed. With the application of social distancing, it reduces the number of positive cases of Covid-19 in the region. Social distancing rules are obeyed by all parties which result in changes during social events such as visiting the sick, mourning, community service, community meetings or RT, RW meetings and so on. This limitation still does not discourage the public from adhering to Covid-19 health protocols such as washing hands, using hand sanitizers, using masks or face shields, keeping a distance from crowds. Sanitation facilities are also provided in the neighbourhood, such as the provision of a hand washing place and hand sanitizer so that it provides comfort for the community round the Karimunjawa environment. The Covid-19 Task Force in Karimunjawa also received APD (Alat Perlindungan Diri) assistance from Karimunjawa investors. 


\subsubsection{Economic Conditions}

The economic condition of tourism in Karimunjawa has dropped dramatically during this pandemic due to the absence of tourists visiting. However, the community is trying to get up by switching their livelihoods apart from tourism income to fulfill their daily needs. This downturn has occurred since March 2020 when the object was closed to the public, so that for about 5 months the community has only relied on income outside of tourism. Livelihoods in question include planting seaweed, fishing and being construction workers. People who have helped tourism actors become jobless because there are no jobs from tourism actors. The tourism actors referred to her include tourism bureau associations, tour boat associations, hotel and homestay associations, transportation associations, street vendors association, catering associations and tour guide associations. This vacancy has actually occurred since January 2020, where January-February is not the right and safe season for water tourism due to the rainy season, high sea waves and strong winds. If the plan is to open in September-October 2020 , then these months are also not the right time for water tourism because of high waves, rain, storms, so it can be estimated that people's income from tourism will not return to normal.

\subsubsection{Sustainable Tourism as Tourism Development After the Covid-19 Pandemic}

In sustainable tourism, pay attention to 3 components, namely economic, social and environmental. To develop sustainable tourism requires a strong commitment from the government, tourism actors and local communities. Tourism in Karimunjawa is included in Kawasan Strategis Pariwisata Nasional (KSPN), as well as Kawasan Strategis Pariwisata Provinsi (KSPP) in Central Java. The reference documents for sustainable tourism development are the Master Plan and Detailed Plan for KSPN Karimunjawa and its surroundings, Rencana Induk Pengembangan Kepariwisataan Provinsi Jawa Tengah Tahun 2012-2027 (Peraturan Daerah Provinsi Jawa Tengah Nomor 10 Tahun 2012), and Rencana Pengelolaan Jangka Panjang Taman Nasional Karimunjawa Tahun 2018-2027.

In the plan to reactivate Taman Nasional Karimunjawa, Jepara, there are 6 (six) stages of management that must be carried out first if the spread of Covid-19 starts to decline. These stages include the stage of preparation, coordination of the parties, strengthening administration, simulation and verification, submission to Menteri Lingkungan Hidup dan Kehutanan (LHK) and approval and trial (Balai Taman Nasional Karimunjawa, 2020). TN Karimunjawa will also propose reactivation phase 2 to Menteri Lingkungan Hidup dan Kehutanan (LHK) dated July 6, 2020. Reactivation of tourism activities still has the opportunity to spread Covid-19 so it requires joint socialization regarding awareness of preventing Covid-19 for the Karimunjawa community.

Sustainable tourism development is a shared responsibility, in this case not only the government makes policies but tourism actors need to support the advancement of tourism in Karimunjawa in particular. Tourists need to change their marketing strategies and approaches that highlight the health and safety of visitors during tourism activities. The implementation of the Covid-19 health protocol needs to be adhered to in making new marketing strategies that can include hotel accommodation, transportation, to cleanliness of tourist areas.

To develop the Karimunjawa area, the Indonesian Ministry of Maritime Affairs and Investment and the Ministry of Transportation will prepare public transportation in the form of buses for the Dewandaru Airport and Legon Bajak Port routes to Karimunjawa city center. This is because the distance from the airport to the city center is around $22 \mathrm{Km}$ and there is no 
public transportation yet, so it is suggested to procure a bus fleet to facilitate tourists and save costs. The Ministry of Tourism issued a tourism policy through UU No. 10 Tahun 2009 concerning Tourism.

Support for sustainable tourism development in the environmental sector has been realized by the government with the existence of Pusat Daur Ulang (PDU) in Karimunjawa Islands, Jepara Regency. This PDU was inaugurated on August 24, 2020. The location of the PDU is located in Dukuh Alang-alang, Desa Karimunjawa which is assistance from Direktorat Jenderal Pengelolaan Sampah Limbah and B3 Kementerian Lingkungan Hidup dan Kehutanan (KLHK). PDU Karimunjawa can accommodate up to 10 tons of waste per day. The collected and sorted garbage will later be brought to the mainland and found to buyers for recycling. The assistance is a form of KLHK's commitment to prevent waste leakage into the sea and reduce plastic waste by up to 75 percent.

Government support, in this case Kementerian Koordinator Bidang Kemaritiman dan Investasi (Kemenko Marves) and the ministries under its coordination, are trying to restore the tourism sector which was hit by the pandemic. Efforts taken are opening access to capital assistance for UMKM Sektor Pariwisata dan Ekonomi Kreatif (Parekraf). A number of access to capital that can be reached by the tourism sector UMKM are Dana Bantuan Insentif Pemerintah (BIP) Kementrian Pariwisata and Ekonomi Kreatif and Dana Program Kemitraan Pertamina. The BIP Fund is an assistance program from the Ministry of Tourism and Creative Economy to increase working capital or investment in order to increase the business capacity and production of creative economy and tourism business actors. The government will distribute IDR 24 billion for 6 sub-sectors of the creative economy and the tourism sector. Regular criteria will receive a maximum of $\mathrm{Rp} 200$ million. Meanwhile, the maximum affirmative is IDR 100 million.

\subsubsection{Tourism 4.0 as A Technology That Supports Tourism Sustainability}

Telecommunication infrastructure in Pulau Karimunjawa is quite complete, the most form of communication means is a private telephone using a wireless network. However, not all providers are available, only certain providers have served this district, such as Telkomsel and Indosat. The distribution and number of communication suggestions on Karimunjawa Island are still lagging behind and not yet advanced. For villages that have not yet entered communication facilities, such as the villages of Kemojan, Parang, and Nyamuk, the same is true for transportation facilities such as cars, motorbikes, bicycles and carts. Scarcity of fuel oil greatly affects the availability of transportation facilities in Karimunjawa.

Local and foreign tourists really need information about the location to be visited. To be able to find out the tourist locations to be visited, tourists can easily search by accessing the internet. Jepara Regency by creating a website, all information needed by potential tourists who will visit Jepara can be seen at www.ticjepara.com which is directly managed by the Jepara Regency Tourism and Culture Office. Starting from the address and list of telephone numbers that can be contacted, list of tourist attractions, list of lodging, list of restaurants, travel, transportation, tour packages, entrance ticket prices for tourist objects, news collections, and even tourist visit statistics are also available on www.ticjepara.com.

Another website that provides information about Karimunjawa is www.visitjawatengah.jatengprov.go.id. This website was developed by the Central Java provincial government with the aim of promoting tourism in Central Java by displaying complete and interesting tourist destination information. The features available on the website include articles, travel plans, tourist destinations, events and adventures. The article covers 
information on tourist destinations with their peculiarities that create their own charm. This information is always updated with the situation in question. The itinerary contains information on tourist attractions, culinary delights, accommodation, travel agents. The event contains information about events held at tourist sites, including Karimunjawa. Adventure includes news regarding outdoor, culinary, shopping, village tours.

Another website that has contributed to promoting Karimunjawa tourism is www.wartawisata.id/jawatengah/kabamatan-jepara. This website is managed nationally so that all tourist destinations in Indonesia are given space here. This website features information about archipelago roaming, priority destinations, 3A (accessibility, amenities and tourist attractions), characters and roles, galleries, your stories, WWI TV. The weakness of this website is that it is not up to date in delivering information. News about Karimunjawa last in December 2019

A special website that displays the general condition of Karimunjawa National Park is www.tnkarimunjawa.id which is managed by the Karimunjawa National Park Office. In this website, visitors can surf to find information about the general condition of Karimunjawa, institutional Karimunjawa National Park, turtle conservation, publications, libraries. Another website is www.disparbud.jepara.go.id which is managed by the Jepara Tourism Office so that the website is institutional in nature. Tourist information is also available and quite complete, but the last update was since before the pandemic.

\section{Conclusion and Recommendation}

Karimunjawa as a marine tourism object located in Jepara Regency has undergone significant changes since the Covid-19 pandemic. Since the closure of this object on March 17,2020 , practically no tourists have visited. This condition has an impact on the surrounding community and especially people who become tourism actors in Karimunjawa. The conditions referred to are environmental, social and economic conditions that are the pillars of tourism sustainability. With the development of sustainable tourism, it is hoped that it will improve the welfare of the community from an economic, social and environmental perspective. With the Covid-19 pandemic, this condition is practically constrained. Environmental conditions during a pandemic are basically affected by the presence or absence of visitors. Environmental cleanliness is maintained, some are not, coral reefs are growing because there are no visitors. Social conditions change the behavior of people who pay more attention to cleanliness than before. The social relations and interactions of the community remain the same, only to be more vigilant in carrying out cultural traditions as recommended by the government. The economic condition has also changed drastically which of course is triggered by the absence of tourist visitors so that there is absolutely no income. The community shifted to other jobs such as fishing, planting seaweed and construction workers.

The difficulties faced by tourism actors and the Karimunjawa community can be a challenge for the government in managing sustainable tourism. The government inaugurated the PDU to answer problems in the environment and economy. Plastic waste that is scattered in the sea can be reduced and recycled so that it can produce added value. The government has formulated old policies and has not formulated policies related to tourism sustainability during the AKB or new normal. The real policy is not from the government alone, but how the tourism actors will make attractive marketing strategies when the new normal is normal and the related objects reopen. Promotions that are carried out need to highlight Karimunjawa's strengths in terms of cleanliness, health and safety. 
Related to the use of technology in building tourism sustainability after the pandemic has not been done much because it is still waiting for readiness to open these destinations. Tourism 4.0 implemented here is by using a website that makes it easy for prospective Karimunjawa visitors to get information related to the object they will visit in the form of information on accommodation, transportation, culinary, object attraction, even local culture or traditions. This pandemic condition can actually be used to provide updated information that illustrates that Karimunjawa is still safe to visit, thus encouraging related parties to immediately decide to open this destination immediately.

\section{References}

[1] N. Pendit, "Ilmu Periwisata dan Pengantar Perdana," Jakarta PT Pradnya Pramita, 1994.

[2] M. Orams, Marine tourism: development, impacts and management. Routledge, 2002.

[3] V. Daniel, "Jangan Tunggu Lagi, Bangkitkan Pariwisata yang Berkelanjutan," Detik News, 2020. [Online]. Available: https://travel.detik.com/travel-news/d-5049874/jangan-tunggu-lagibangkitkan-pariwisata-yang-berkelanjutan.

[4] J. Urbančič et al., "Expansion of Technology Utilization Through Tourism 4.0 in Slovenia," in Handbook of Research on Smart Technology Applications in the Tourism Industry, IGI Global, 2020, pp. 229-253.

[5] J. I. Richardson and M. Fluker, Understanding and managing tourism. Pearson Education Australia, 2004.

[6] B. Boniface, C. Cooper, and R. Cooper, Worldwide destinations. Routledge, 2006.

[7] U. S. Peceny, J. Urbančič, S. Mokorel, V. Kuralt, and T. Ilijaš, "Tourism 4.0: Challenges in marketing a paradigm shift," Consum. Behav. Mark., pp. 1-19, 2019.

[8] Manjari and R. M. Eka, "ntroducing Tourism 4.0: What is It and How Do We Get Here?," 2018. [Online]. Available: https://forbil.org/id/article/211/introducing-tourism-40-what-isit-and-howdo-we-get-here. [Accessed: 28-Dec-2019].

[9] T. Pencarelli, "The digital revolution in the travel and tourism industry," Inf. Technol. Tour., vol. 22, no. 3, pp. 455-476, 2020.

[10] M. B. Miles, A. M. Huberman, M. A. Huberman, and M. Huberman, Qualitative data analysis: An expanded sourcebook. sage, 1994. 